\title{
ÉTICA DA RECEPTIVIDADE: ASPECTOS DE UMA FILOSOFIA MORAL SEGUNDO JEAN-FRANÇOIS LYOTARD
}

\author{
Lars Leeten ${ }^{1}$
}

RESUMO: O presente artigo aborda a dimensão ética no pensamento de Jean-François Lyotard. Como conceito decisivo para essa relação, é aqui proposto o conceito de receptividade (passibilité). Partindo dele, deseja-se mostrar que é possível reconstruir uma concepção de responsabilidade ética no pensamento do filósofo francês, a qual se coloca em sentido diametralmente oposto à concepçáo de autonomia: a obrigaçáo ética se torna por conta disso afetiva, fundada e repousando na capacidade de se deixar falar. Com vistas a uma determinaçâo mais acurada dessa posição, serão consultadas as reflexões de Lyotard acerca da filosofia da linguagem em Le Differénd: a concepção do "acontecimento da fase" se deixa mostrar na ética do diálogo, que deixa espaço para a assimetria, alteridade e transformação. O pensamento do conflito insolúvel (différend) mostra-se como plenamente implicado com essa ética.

PALAVRAS-CHAVE: Lyotard. Ética. Filosofia moral. Pós-modernidade. Conflito.

Hoje há professores para tudo, apenas não para a sensibilidade.

(Henri Cartier-Bresson)

Atualmente, parece plenamente compreensível que o pensamento chamado pós-moderno tenha tido desde o seu início um sentido ético. Quando alguns autores dessa corrente bastante heterogênea começaram a tornar explícito esse lado mais implícito de seu pensamento, no início dos anos noventa, isso ocorreu táo inesperadamente que se falou de uma ethical turn. $^{2}$ Desde entâo se tornou comum relacionar projetos descontrutivos e filosofias da diferença com o tema da justiça ou entender ataques à autonomia como intervençáo em nome da alteridade dos outros. A mudança de sentido da subversão pós-moderna e pós-estruturalista é um dos mais significativos argumentos para se começar a discutir seriamente os seus representantes.

\footnotetext{
${ }^{1}$ Instituto de Filosofia, Universidade de Hildesheim, Alemanha. E-mail: leeten@uni-hildesheim.de

${ }^{2}$ Um dos primeiros claros sinais disso foi o escrito de Jacques Derrida, Force de loi (DERRIDA, 1994). Aspectos fundamentais de uma ética pós-moderna abordaram inicialmente CRITCHLEY (1999) e BAUMANN (1993).
} 
O estilo de pensamento pós-moderno se tornou apresentável, porque ele passou a ser percebido não como relativismo sem responsabilidade, mas como um pensamento que possui o seu próprio rigor, o qual, por sua vez, não é primordialmente epistemológico.

Também o pensamento de um dos mais eminentes representantes da pós-modernidade, Jean-François Lyotard, possui perceptivelmente um conteúdo ético. Nunca foi efetivamente explicitado - nem pelo próprio Lyotard, nem também (ou apenas em mençóes) por seus comentadores ${ }^{3}-$ no que ele consiste exatamente, ou qual ética poderia estar relacionada à filosofia do diferendo (différend). ${ }^{4} \mathrm{O}$ que então poderia significar ética, em Lyotard? Essa questão determina a reflexão a seguir. Inicialmente se faz presente a dificuldade segundo a qual, em lugar algum, a ética surge como disciplina filosófica nos escritos de Lyotard. Na sua obra, não há nenhuma clara separação entre filosofia prática e teórica. $\mathrm{O}$ ético não é para ele nenhuma espécie singular dentre outras formas de discurso, algo como o discurso das “proposiçóes prescritivas". Ele está, todavia, eminentemente presente e por esse mesmo motivo desempenha um papel bastante fundamental no seu pensamento. Como então descrever esse relevante papel do ético, em Lyotard? Como a dimensão ética em seu pensamento se deixa determinar?

Eu vou me aproximar dessa questáo, a partir da consideração inicial que se faz presente em $A$ condição pós-moderna (1). Em um segundo momento, será analisada a concepção de différend (2). Tendo isso como base, será proposto o conceito de receptividade ou abertura (passibilité) ${ }^{5}$, enquanto conceito fundamental para a determinação do conteúdo ético do pensamento de Lyotard (3). Por último, surge a questão de qual elemento a filosofia de Lyotard nos dá, tendo em vista a empreitada que habitualmente entendemos por ética (4).

3 Como novas tentativas, conferir, por exemplo, DE SCHRIJVER (2010), DEKENS (2000), WILLIAMS (2000). Lyotard é então lido a partir de Lévinas e, antes de tudo, de Kant. Que Lyotard teria ido muito além de Derrida consiste a interpretação de James Hatley, em "Lyotard, Lévinas, and the phrasing of the ethical“ (HATLEY, 2002). Há menos aspectos, a despeito do título instigante, em Jean-François Lyotard, Moralités postmodernes (LYOTARD, 1993).

${ }^{4}$ A expressão francesa différend indica um conflito que não se deixa decidir por meio de uma regra. Optouse então pelo neologismo diferendo, tendo-se em vista com ele uma certa noção de continuidade, de condição conflitante, que não necessita ou remete a uma conclusão. Este é o sentido que se deseja expressar com a noçáo, mesmo quando ela for citada no original em francês (NT).

${ }^{5}$ Lyotard assimila o conceito de passibilité da filosofia de Levinas. Optou-se aqui pela tradução receptividade, todavia, deseja-se indicar que o termo, tal como pensado por Lyotard, comporta a noção de abertura, a qual é pressuposta aqui. 
1.

$\mathrm{Na}$ introdução de $A$ condição pós-moderna, Lyotard apresenta sua investigação como uma tentativa de responder à questão da possibilidade de uma "[...] legitimação do conhecimento posterior as grandes narrativas" (LYOTARD, 1979 , p. 7-9). Isso soa muito mais como epistemologia normativa do que como análise sociológica descritiva, mas rapidamente se constata que essa legitimação necessita decorrer da prática linguística e da comunicação (LYOTARD, 1979, p. 68). Lyotard pressupóe, conjuntamente com Wittgenstein, que, no fundamento de todo saber (LYOTARD, 1979, p. 36), repousa o modo como consiste a facticidade (Gegebenheit) de uma forma de vida, o poder-fazer, o poder-viver e o poder-ouvir. Para Lyotard, isso significa que a forma fundamental do saber se deixa conceber apenas de maneira narrativa. A base de todo pronunciamento (Aussagen) proposicional denotativo necessita ser articulada em narrativas, e estas determinam os critérios das ciências. $\mathrm{O}$ narrativo náo pode ser autorizado previamente, ele alcança a sua autoridade performativamente. Os pressupostos não discursivos do saber e do conhecimento acham as suas formas explicitas em exitosos atos narrativos.

Se a derrocada das grands récits da modernidade possibilita tornar atual a questão da legitimação, esta não é, todavia, nenhuma questão normativa, a qual se coloca em diferenciação ante a questão do conhecimento. Legitimar o saber como saber significa relatar práticas. Aqui podemos nos ver colocados em um nível que está além das diferenciaçóes entre normatividade e conhecimento, ou entre ser e dever, que são tão manifestas no mundo científico. Se se compreende que a ciência é um discurso próprio, então tem-se simultaneamente sempre a ver com a legitimação do saber e com a questáo da autoridade da legislaçâo. Por isso se tornou válido, desde Platão, escreve Lyotard, que a decisão sobre a verdade seja uma questão de justiça: "C'est depuis Platon que la question de la légitimation de la science se trouve indissociablement connexe de celle de la légitimation du législateur" (LYOTARD, 1979, p. 20).

Onde as grandes narrativas não mais logram convencer, não é levantada apenas uma questão epistemológica. $\mathrm{O}$ discurso da ciência é basicamente um discurso ético-político, que, por exemplo, evidencia que a deslegitimação do saber traz consigo a desmoralização do pesquisador (LYOTARD, 1979, p. 19). A questão de qual narrativa é tida como válida se relaciona com a autoridade de ter a permissão de constituir narrativas sobre as quais o saber se baseia. 
Isso tem a ver com a determinação de regras, critérios e medidas. ${ }^{6} \mathrm{Na}$ pósmodernidade, encontramos muitas dessas narrativas, muitos critérios e muitas regras. Lyotard naturalmente não tem como meta responder à pergunta sobre o que deveria valer como conhecimento ou reorientar a produção de conhecimento. Ele não quer restituir a univocidade do saber, por meio de uma decisão político-moral. Para ele, isso remete à ocupação com diferenças que não eliminam as diferenças. Ele apresenta essa situação, em $A$ condição pósmoderna, como ética e não como epistemológica: "Il faut donc parvenir à une idée et à une pratique de la justice qui ne soit pas liée à celles du consensus" (LYOTARD, 1979, p. 106). Tal práxis da justiça de lidar com diferenças começa, segundo Lyotard, com o reconhecimento da pluralidade dos jogos de linguagem (LYOTARD, 1979, p. 11). Mas, primeiramente em Le Différend, Lyotard tenta desenvolver conceitos para tal pensamento. Nisso, o seu procedimento é, em muitos aspectos, ainda mais radical. Todavia, ao mesmo tempo, a sua pretensão de salvar a honra do pensador - “[...] sauver l'honneur de penser” (LYOTARD, 1983, p. 9) ${ }^{7}$ - é mais resoluta. Deve-se então tentar compreender mais propriamente a dimensão ética no pensamento de Lyotard sob a perspectiva de Le Différend.

2.

Em Le Différend, Lyotard não se ocupa mais com análises sociológicas, remetendo-se mais significativamente à filosofia da linguagem. A linguistic turn consiste, segundo a sua indicação, em um contexto dessa obra (LYOTARD, 1983, p. 10). Poder-se-ia pensar que a base para o seu conceito de justiça seria a comunicação, como em $A$ condição pós-moderna. Mas este não é o caso. $\mathrm{O}$ conceito central, em Le Différend, é o conceito de frase. A frase não é nenhum ato de fala ou uma forma gramatical, porém um acontecimento. ${ }^{8}$ É um acontecimento entre um emissor, um endereçado, um referente e uma significação. A única coisa da qual não se deve oportunamente duvidar é que existe frase, e o tempo e de que uma frase segue a outra (vide LYOTARD, 1983, p. 92). Mediante isso, a

${ }^{6} \mathrm{O}$ recurso frequente de Lyotard à retórica e à sofística lembra que ele conscientemente recorre à ideia segundo a qual a discussão sobre o saber pode ser separada da discussão sobre a moral. Saber e moral estấo continuamente relacionados. Em uma fase de deslegitimação, essa relação chega apenas à consciência. Seria possível descrever a situaçáo da pós-modernidade de acordo com a ideia de que a relação entre ciência e ética está em jogo de uma nova maneira.

${ }^{7}$ Com respeito ao significado dessa fórmula, vide GASCHÉ, 2007.

${ }^{8}$ Acerca dessa discussão, vide KÖVEKER, 2004. 
frase e o acontecimento frasal pressupóem tanto a frase cognitiva e a constatação da efetividade, como o sujeito. As posiçóes do emissor e do receptor, o referente e o significado, podem se deslocar com cada frase; cada frase forma um universo autônomo. Cada frase subsequente pode suprimir a frase anterior, ao possibilitar um universo novo. Nada garante que o mundo permaneça o mesmo, pois, enquanto a concatenação mesma de frases é necessária, a espécie de concatenação é totalmente contingente (LYOTARD, 1983, p. 121). Certamente existem espécies de discursos que seguem determinadas formas de concatenaçáo, mas a respectiva frase seguinte não está ligada a essa regra. Ela pode propriamente mudar a forma de discurso, e não existe nenhuma metarregra para a concatenação, além das formas de discurso.

Com isso, o diferendo é inevitável. Um différend á sabidamente um conflito insolúvel, para o qual não há nenhuma regra decisiva apropriada, a qual possa valer para ambas as partes. ${ }^{9}$ Se um caso como esse for tratado como um litígio, então será decidido segundo a regra de uma forma de discurso. Sob a dominância dessa regra, as pretensões da outra parte não poderiam nem ser formuladas. O discurso submetido permanece, por assim dizer, silente e as suas regras ocultas. Segundo Lyotard, essa forma de repressão de um diferendo dessa natureza é uma injustiça - não uma injustiça em sentido jurídico, porém, uma injustiça moral e ética. Contrariamente a isso se dá a atuação (enjeu) da posição de Lyotard em testemunhar o diferendo (LYOTARD, 1983, p. 10). Decorre um dano, se a circunstância de uma forma de discurso for avaliada por meio de regras de uma outra forma de discurso. Se a forma de discurso lesada não tem nenhuma possibilidade de manifestar o dano - de apresentálo - ela se torna vítima. Uma injustiça é um dano que o lesado não pode demonstrar, porque lhe faltam os meios para isso (LYOTARD, 1983, p. 17 e seg.). Porém, o diferendo está presente em toda transição de uma frase para outra frase. Em uma frase concatenada com outra frase, estão em jogo pensamento, conhecimento, ética, política, história e ser, ao mesmo tempo (LYOTARD, 1983, p. 10). Todo sistema, toda unificação ocultaria essa condição. Toda tentativa de superar a contingência e a temporalidade da concatenaçáo, todo controle dos acontecimentos frasais, através de metarregras, ultrapassaria o conflito e traria, com isso, injustiça consigo.

${ }^{9}$ Vide LYOTARD, 1983, p. 8, a propósito do que isso significa: "A la différence d'un litige, un différend serait un cas de conflit entre deux parties (au moins) qui ne pourrait pas être tranché éqitablement faute d'une règle de jugement applicable aux deux argumentations". 
Dessa maneira, delineia-se um pouco mais o posicionamento ético de Lyotard. A filosofia do conflito quer manter presente o náo representado, o náo formulado, o não normatizado. Esta é a "ideia" e a "práxis da justiça". Realizar essa práxis significa buscar regras não percebidas, o que parece significar: articular aquilo que não foi articulado. A meta, porém, não é algo como a formulação derradeira de regras. Tal práxis da justiça significa muito mais uma práxis que quer se efetivar sempre no novo. A determinação empreendida por Lyotard da filosofia, enquanto discurso que busca regras, reflete a determinação desta tarefa. ${ }^{10}$ Isso diz respeito a aprender a ver o outro de todo acontecimento frasal - concerne ao atentar para o incidente, “[...] qu'on prenne garde à l'occurence” (LYOTARD, 1983, p. 13). A busca por regras se dirige ao especifico dos casos particulares, não à explicação de normas. A dissociação crítica dos tipos de discurso serve antes de tudo a essa meta, a qual não se direciona a achar possibilidades para a concatenação legítima, todavia, é parte de um trabalho atinente aos idiomas do diferendo (LYOTARD, 1983, p. 29).

Testemunhar oposiçôes significa, por conseguinte, testemunhar a contingência de toda determinaçáo ou, ainda, aprender a sentir a instabilidade que subjaz a cada nova construção frasal (LYOTARD, 1983, p. 28). Todavia, se a dimensão ética repousa no domínio do irrepresentável do sentimento, pode-se ainda determiná-la filosoficamente? Poder-se-ia ainda questionar, de modo platônico: essa práxis da justiça, enquanto práxis da percepção sensível, é passivel de ser ensinada? A busca de regras é claramente um traço da reflexão estética, que é a ética no núcleo de uma teoria da percepção. ${ }^{11} \mathrm{Na}$ seção seguinte, gostaria de tentar determinar de modo mais acurado a dimensão ética do pensamento do diferendo.

3.

Lyotard assenta o local do diferendo onde algo, que deve ser comunicado em frases, ainda aguarda. ${ }^{12}$ Se esse lugar é ao mesmo tempo o lugar do ético, pode-se então dizer que o ético é posto em jogo quando ainda não está

\footnotetext{
${ }^{10}$ Vide LYOTARD, 1983, p. 94, ou a referência sob o título "Modus", no capítulo inicial de Le differénd: quando Lyotard determina o filosófico, nesse contexto, como reflexivo (LYOTARD, 1983, p. 12); com isso, não se verifica nenhuma autoconsideração de um sujeito que é transparente para si mesmo.

${ }^{11}$ Conferir especialmente as reflexôes acerca de Kant, em: LYOTARD, 1991.

${ }^{12}$ LYOTARD (1983, p. 28): "Le différend est l'état instable et l'instant du langage où quelque chose qui doit pouvoir être mis en phrases ne peut pas l'être encore".
} 
decidido qual frase deve vir em seguida. Com isso não se deve naturalmente pensar, no horizonte do pensamento lyotardiano, que a ética adentra em cena em um momento de decisão, quando um sujeito busca por fundamentos para agir de um certo modo. O acontecimento frasal repousa, com já dito, antes da efetividade, do tempo e antes das normas e também antes do sujeito. Isso pareceu confuso em muitos intérpretes de Le différend. Por esse motivo, Manfred Frank mencionou o paradoxo de uma ética sem sujeito e, de forma bastante similar, Honneth levantou a objeção de que Lyotard oscila entre argumentação sobre filosofia da linguagem e filosofia do sujeito. ${ }^{13}$ A questão central é, portanto: como se pode querer encenar uma ética, quando se pensa a partir de frases - e ainda mais em frases que não são nem entendidas como atos de fala, porém como acontecimentos? Não precisamos de sujeitos que empreendam os atos de fala, quando se deseja tratar de ética?

Lyotard se refere manifestamente à posição da alteridade ética com uma consequência que ultrapassa em muito os cenários convencionais de uma intersubjetivação ou sociologização do sujeito. Segundo ele, o ético pode ser encontrado onde se está de forma mais distanciada da autonomia. Enquanto a ética do sujeito autônomo é uma ética da espontaneidade e da autorregulação, a ética do diferendo é uma ética da sensibilidade e da atenção para com outras leis. A ética das autorregulaçáo visa a que o sujeito permaneça idêntico a si mesmo. Para que eu mesmo possa me fornecer uma lei, eu necessito aspirar à soberania de permanecer "o mesmo" de caso a caso. Eu necessito ser um sujeito idêntico a mim e não devo me alterar no tênue estado do diferendo. Lyotard chega à conclusão de que o emissor do compromisso necessita ser idêntico ao receptor do compromisso (LYOTARD, 1983, p. 183 e seg.). Nesse sentido, porém, a atenção referente ao acontecimento estaria imediatamente perdida. Um sujeito inalterável não pode ser sensível para o diferendo. $\mathrm{O} \mathrm{Eu}$ autônomo é, pelo contrário, predestinado a obliterar esse conflito. A ética do sujeito permanece, por isso, sempre uma ética de direita, uma ética das normas; o conceito de justiça permanece jurídico.

Um conceito ético de justiça necessita, contrariamente a isso, estar antes da identidade do sujeito e, assim, antes da autonomia. Deve-se entender, logo, que o sujeito na reflexão de Lyotard é fragmentado em um infinito número de acontecimentos frasais. Estes são lugares do permanente nascimento do

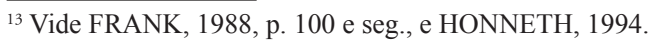


sujeito. ${ }^{14} \mathrm{O}$ que - ou quem ele é - é decidido pela forma como emissor e receptor se situam nos respectivos acontecimentos frasais, por conseguinte, qual posição eles tomam no universo frasal. Nos casos em que a frase ainda não é formulada, isso ainda não está decidido. Seria possível querer dizer: se o diferendo é o momento de incerteza, no qual algo deve ser proferido por meio das frases, mas ainda não foi determinado como isso deve ocorrer, é também o momento em que se está diante da decisão de quem alguém é ou será. No movimento de concatenaçáo das frases ou - o que é o mesmo - no decorrer do tempo, pode-se em princípio decidir isso novamente, a cada novo momento. A sensibilidade, que constitui o centro da perspectiva ética de Lyotard, é uma sensibilidade precisamente para essa possibilidade. É um momento de abertura para a náo identidade, do envolver-se, que precede toda ação espontânea.

Essa dimensão pré-subjetiva da responsabilidade é aquela que Lyotard e Lévinas desenvolvem como abertura (passibilité). O ético relaciona-se com isso, pois inicialmente o mesmo não é nem autônomo e nem soberano. Conhece-se a respectiva cena original do pensamento de Lévinas, à qual Lyotard se remete, em um ponto central. Um compromisso, que decorre da pretensão do outro e não de uma autodeterminaçáo, está além do controle e decisivamente também da compreensão de si mesmo (vide LÉVINAS, 1961). A prescrição é mais propriamente descrita, segundo o pensamento nuclear de Lévinas, quando ela é vista como um escândalo para os compromissados: o outro ocorre para o eu, quando ele se manifesta no horizonte deste, ele vai além do horizonte de sentido do Eu e se coloca totalmente além de suas possibilidades de experiências. ${ }^{15}$ Lyotard descreve esse assalto do outro no Eu, na sua terminologia, da seguinte maneira: o outro expulsa o Eu da posição emissora e faz dele um pleno receptor. O Eu se torna Tu e debela totalmente o tu deves (LYOTARD, 1983, p. 163). Esse acontecimento constitui o início de todo comprometimento. Como acontecimento afetivo, como "événement du sentiment" (LYOTARD, 1983, p. 163), precede também o conhecer. $\mathrm{O}$ Eu não poder propriamente entender o emissor, ele percebe apenas a regulação, que há regulação - "[...] la simple prescription qu'il y ait de la prescription” (LYOTARD, 1983, p. 163). Nesse sentido, a obrigação moral se baseia plenamente na capacidade de se deixar aproveitar da abertura, da passibilité (Vide LYOTARD, 1983, p. 165). Essa é, ao mesmo tempo, a condição do sujeito e a condição da responsabilidade

\footnotetext{
${ }^{14}$ Essas descriçōes encontram-se em Le postmoderne explique aux enfants (LYOTARD, 1986a), assim como em Leçons sur l'analytique du sublime (LYOTARD, 1991).
}

${ }^{15}$ LYOTARD (1983, p. 162): “Le moi ne procède pas de l'autre; L'autre advient au moi". 
ética e, desse modo, para Lyotard, a totalidade da ética: "Cette passibilité n'est pourtant pas une condition de possibilité de l'éthique, l'archè de l'obligation. [...] Elle est déjà toute l'éthique, elle comporte ensemble ses deux faces, la liberté et la persécution" (LYOTARD, 1983, p. 165).

Se isso fosse ultrapassado, poder-se-ia ainda dizer que novamente se estaria no domínio da ontologia - na esfera do Ser e do sujeito ativo - e se teria com isso ocultado o conflito. Assim, pode-se entender que a pretensão ética, segundo Lyotard, resulta do acontecimento da frase e não do encontro com outra pessoa. Ele até mesmo evita falar dos Outros (l'autrui) e se refere preferencialmente ao Outro (l'autre). Segundo Lyotard, apenas se pode dizer que a frase traz um compromisso consigo, quando ela compromete o seu receptor. ${ }^{16}$ Em um discurso de conhecimento, que faz do Tu um Eu, um tal comprometimento não se deixa de forma alguma representar (LYOTARD, 1983, p. 171). O universo ético repousa sobre o patamar das condiçôes - é a condição do remetimento à pessoa, da construção discursiva, da construção de mundo. Por isso, não é uma forma de discurso, dentre outras. Em verdade, todos os comprometimentos - secundário, instrumental - são derivados dela.

No segundo excurso, sobre Kant, em Le différend, Lyotard acentua isso como problema da dedução da lei moral em Kant (LYOTARD, 1983, p. 173185). Para ele, na Fundamentaçâo, Kant necessita decisivamente confiar em um princípio de liberdade dado ou "fato da razão", porque o pensamento de uma dedução da lei moral por si só contém uma objetivação. Através da objetivação da citação de uma frase prescritiva é, porém, eliminada toda força obrigatória dessa frase. Por isso, a lei necessita permanecer derivada. O que resulta é unicamente a representaçáo de uma irrepresentável ideia em signos (LYOTARD, 1983, p. 178 ou 185).

4.

Qual contribuição para a ética filosófica poderia trazer a filosofia do diferendo de Lyotard, quando sob essa ética se entende a tentativa de aperfeiçoar e refinar as práticas da formação de juízos e solução de conflitos? Se tal questão suscita interesse, antes de qualquer coisa, se achará tal pensamento ofensivo, de sorte que a ética poderia não mais ser que algo relacionado à suscetibilidade.

${ }^{16}$ LYOTARD (1983, p. 159): “Une phrase est obligatoire si son destinataire est obligé”. 
A ética não pode verdadeiramente ser mais do que isso? Não necessita ser mais do que isso?

Naturalmente se poderia acentuar que a posição de Lyotard, de forma muito geral, pode ter uma função moral crítica, do mesmo modo que, desde Nietzsche, este é um aspecto decisivo da reflexão ética. Lyotard movimenta para o centro, tâo radicalmente como quase nenhum outro pensador, o singular, o não dizível, o individual e o incalculável fluxo da experiência. Isso ocorre não com o objetivo de destruir a possibilidade de ordenação e de normas. Lyotard alude frequentemente, em seus escritos, a "anuviamento" e a "entusiasmo" (vide LYOTARD, 1986a). A partir disso, esse pensamento mostra-se como lembrete contra um falso otimismo do pensar. Le différend é uma lembrança de que nós náo podemos coagir nada no pensamento, nem mesmo uma conciliação final, e que nunca se deveria acreditar que se encontrou a forma do mundo, o sujeito derradeiro, a norma final. Uma crença dessa natureza é sempre autoengano. Para a ética, isso significa que não pode haver último "sistema de justiça”. Em verdade, na prática, há apenas novas decisóes.

Tal interpretação indica certamente algo válido, porém, ela negligencia o sentido rigoroso que as reflexóes de Lyotard podem desenvolver para a imagem que se faz do discurso moral. Nesse sentido, o estilo da filosofia da linguagem, em Le différend, tem uma função exata e determinada, que ainda deve ser descoberta: o passo "do sujeito à linguagem" não é terminantemente uma consequência radical do ponto de vista segundo o qual a existência de seres humanos e a estrutura das formas de vida constituem necessariamente o contexto dos processos linguísticos e simbólicos. No estreito quadro da teoria dos atos de fala, não se pode representar corretamente esse aspecto, pois nele aptos falantes já necessitam ser sempre pressupostos. As reflexóes de Lyotard sobre o "acontecimento da frase" se deixam melhor evidenciar em uma ética na qual o debate ético não sumariamente sugere um debate entre sujeitos autônomos, mas deixa espaço para a assimetria, alteridade, invenção e alteração, em um processo de desenvolvimento comunicativo. $\mathrm{O}$ pensamento do diferendo refere-se a um domínio pré-cognitivo, a partir do qual uma pessoa cria propriamente o potencial para perceber novos casos e os julgar. Cria o potencial de estar aberta a outras pessoas e alterar as próprias configuraçóes éticas, portanto, ao mesmo tempo, cria a possibilidade de se tornar uma outra pessoa. Com Lyotard se poderia aprender qual papel esses aspectos desempenham, no discurso moral. Uma pessoa que é incapaz de perceber os "momentos instáveis" da oposição, que é cega para o momento 
da linguagem no qual "algo, que deveria poder ser trazido em frases, aguarda”, não é propriamente requerida para este discurso. Ela não será, com relação a ele - caso se queira dizer assim - nem mesmo um ouvinte apropriado. Quando se faz referência apenas a normas que já se conhecem e não se procura por novas regras, não se entendeu ao que se refere a compreensão moral. Efetivamente, a argumentação moral é uma prática de atenção e, desse modo, uma prática propriamente ética.

A filosofia de Lyotard se direciona, com isso, a um discurso ético especial e pretensioso. "Testemunhar" o diferendo significa direcionar o olhar para aquilo que as regras gerais não deixam fixar. $\mathrm{O}$ homem pós-moderno de Lyotard, que se volta à pluralidade e vê chegar a hora de filosofar - "l'heure de philosopher" (LYOTARD, 1983, p. 10) -, tem uma dura tarefa a realizar, ao apenas fornecer atos de fala adjudicáveis e ao fornecer argumentos. Para ele, ética e discurso moral possuem uma dimensão receptiva, que requer uma constante atenção para o novo e para o outro. A ideia de justiça não se deixa realizar sozinha, por meio de normas, pois as regras não nos podem dizer qual uso é apropriado para casos particulares. O modelo igualdade de tratamento necessita ser complementado por um momento da não igualdade de tratamento e da responsabilidade diante do singular. A moral está em jogo a cada momento, de uma forma nova. A mensagem de Lyotard para o filósofo moral satisfeito consigo mesmo, que acredita ter resolvido a tarefa moral, é: a tarefa ética nunca está resolvida, ela começa novamente, sempre do início. ${ }^{17}$

(Tradução de Roberto Barros, Professor do Programa de Pós-Graduação da Faculdade de Filosofia da UFPA).

${ }^{17}$ Este texto foi apresentado no "Colóquio sobre a pós-modernidade", organizado pela Faculdade de Filosofia da Universidade Federal do Pará (UFPA), em Belém, em setembro de 2009. Agradeço aos participantes, principalmente aos professores Roberto Barros (UFPA), Marco Brusotti (Lecce/Itália), Ernani Chaves (UFPA), Nelson Souza (UFPA) e Nilson Oliveira (Revista Polichinello), pelos úteis comentários. 
LEETEN, Lars. Ethics of receptivity: aspects of moral philosophy in Jean-François Lyotard. Trans/Form/Ação, Marília, v. 38, n. 1, p. 133-146, Jan./Abr., 2015.

\begin{abstract}
This contribution examines the ethical dimension in the thinking of Jean-François Lyotard. It is shown that receptivity (passibilité) is crucial to its understanding. On these grounds, ethical responsibility can be conceived as fundamentally different from the standard conceptions of autonomy: ethical obligation has its sources in affection and is founded by a capacity of responsivity. This position is further developed by drawing on Lyotard's thoughts on language in Le Différend: the idea of a "sentence event" can be conceptualized within the framework of an ethics of dialogue, which leaves room for asymmetry, alterity, and transformation. The philosophy of the irreconcilable conflict (différend) turns out to be a form of ethics in this sense.
\end{abstract}

KEYWORDS: Lyotard. Ethics. Moral Philosophy. Postmodernism. Conflict.

\title{
REFERÊNCIAS
}

BAUMANN, Zygmunt. Postmodern ethics. Oxford: Blackwell, 1993.

CRITCHLEY, Simon. The Ethics of deconstruction: Derrida and Lévinas. Edinburgh: Edinburgh University Press, 1999.

DEKENS, Olivier. Lyotard et la philosophie (du) politique. Paris: Kimé, 2000.

DERRIDA, Jacques. Force de loi: le fondement mystique de l'autorité. Paris: Galilée, 1994.

DE SCHRIJVER, Georges. The political ethics of Jean-François Lyotard and Jacques Derrida. Leuven: Peeters, 2010.

FRANK, Manfred. Die Grenzen der Verständigung: ein Geistergespräch zwischen Lyotard und Habermas. Frankfurt am Main: Suhrkamp, 1988.

GASCHÉ, Rodolphe. Saving the Honor of Thinking: On Jean-François Lyotard. In: NOUVET, Claire; STAHULJAK, Zrinka; STILL, Kent (Eds.). Minima Memoria: in the wake of Jean-François Lyotard. Stanford: Stanford University Press, 2007. p. 27-48.

HATLEY, James. Lyotard, Lévinas, and the phrasing of the ethical. In: SILVERMAN, Hugh J. (Ed.). Lyotard: philosophy, politics, and the sublime. London: Routledge, 2002. p. 75-83.

HONNETH, Axel. Das Andere der Gerechtigkeit. Habermas und die ethische Herausforderung der Postmoderne. Deutsche Zeitschrift für Philosophie, p. 195-220, 1994.

KÖVEKER, Dietmar. Sprechakte und oder Satzereignisse? Zu den konkurrierenden Sprachkonzeptionen von Apel/Habermas und Lyotard. In: KÖVEKER, Dietmar (Ed.). 
Im Wider streit der Diskurse: Jean-François Lyotard und die Idee der Verständigung im Zeitalter globaler Kommunikation, Berlin: Berliner Wissenschafts-Verlag, 2004.

LÉVINAS, Emmanuel. Totalité et infini: essai sur l'exteriorité. La Haye: Nijhoff, 1961.

LYOTARD, Jean-François. La condition postmoderne: rapport sur le savoir. Paris: Editions de Minuits, 1979.

. Leçons sur l'analytique du sublime. Paris: Galilée, 1991.

Le différend. Paris: Editions de Minuits, 1983.

. L'Enthousiasme. Paris: Galilée, 1986a.

$1986 b$. . Le Postmoderne expliqué aux enfants: Correspondance 1982-1985. Paris: Galilée, Moralités postmodernes. Paris: Galilée, 1993.

WILLIAMS, James. Lyotard and the Political. London: Routledge, 2000.

Recebido em: 26/10/14

Aceito em: 08/12/14 
LEETEN, L. 